\title{
Suggestion of an Abnormal Anion Exchange Mechanism in Sweat Glands of Cystic Fibrosis Patients
}

\author{
PAUL M. QUINTON ${ }^{(31)}$ \\ Division of Biomedical Sciences, University of California, Riverside, Riverside, California and Department of \\ Physiology, UCLA School of Medicine, Los Angeles, California, USA
}

\begin{abstract}
Summary
The physiological basis for the defect in $\mathrm{NaCl}$ reabsorption in cystic fibrosis (CF) sweat glands is not known. We have systematically followed the concentrations of the three major inorganic electrolytes in sweat as a function of single gland sweat rate in patients with $\mathrm{CF}$ and normal individuals. The result demonstrates that (1) at low sweat rates, sweat glands of CF individuals can reduce $\mathrm{NaCl}$ concentrations to normal levels and (2) that the concentration of organic anions and/or $\mathrm{HCO}_{3}$ in $\mathrm{CF}$ sweat is substantially less than in normal sweat.

\section{Speculation}

Present data and other findings suggest that $\mathrm{Na} / \mathrm{K}$ transport and a postulated $\mathrm{Na} / \mathrm{H}$ exchange are normal, but that a postulated anion exchange may be defective in cystic fibrosis sweat glands. These observations suggest an underlying transport genetic abnormality, which might explain observed abnormalities in cystic fibrosis exocrine gland secretions in general.
\end{abstract}

Almost without exception, the fluid secreted by exocrine glands in cystic fibrosis (CF) are either altered in volume or composition. For example, the volume of pancreatic secretions formed under similar conditions of stimulation is only about $10 \%$ of normal (11). On the other hand, the volume of submaxillary salivary secretions is normal but the concentrations of $\mathrm{Na}$ and $\mathrm{K}$ are elevated in these fluids (18).

Of the known abnormalities in exocrine secretions, an elevated concentration of $\mathrm{NaCl}$ in sweat from cystic fibrosis indivduals is one of the most characteristic expressions of the disease. In children, a sweat $\mathrm{Cl}$ concentration greater than $60 \mathrm{meq} /$ liter almost without exception indicates a positive diagnosis while a $\mathrm{Cl}$ concentration less than $50 \mathrm{meq} /$ liter almost as certainly rules out the diagnosis (5). Even though this alteration has proven most useful in diagnosis and has been the subject of much investigation, the underlying basis of the physiologic defect remains unknown.

With few exceptions $(14,17,26)$, almost all previous investigations of the sweat defect in cystic fibrosis have studied whole sweat collected from the body surface. Most of these studies were limited to the analysis of one of two of the major electrolytes present in sweat. These investigations have the advantage of presenting the average function of numerous glands, but suffer from the disadvantages of being unable to: (1) account for the behavior of individual glands and (2) to follow the presence of the several major components of sweat simultaneously.

With the present study, we have examined secretions of single glands from both cystic fibrosis and normal individuals, using techniques of $\mathrm{x}$-ray microanalysis.

\section{MATERIALS AND METHODS}

Subjects. Informed consent forms were obtained from four normal volunteers, ages 22-28 years, and from 5 individuals diagnosed with cystic fibrosis and followed at the UCLA cystic fibrosis clinic with ages 20-34 years.

Collection. Sweat was collected from the volar surface of the forearm of all subjects. Glands were stimulated to secrete by iontophoresing a solution of $1 \%$ bethanecol into an area of approximately $40 \mathrm{~cm}^{2}$ with a current of $1.8 \mathrm{~mA}$ applied for $5 \mathrm{~min}$. In order to collect sweat secretions from single glands, the stimulated area was then washed thoroughly with distilled water, wiped briefly with ethanol, dried thoroughly, and coated with watersaturated mineral oil. A small well was then strapped to the arm and filled with water-saturated mineral oil. With the aid of a dissecting microscope, individual sweat droplets were visualized and collected in constant bore capillaries (66 $\mu \mathrm{m}$ inside diameter) between oil blocks. Samples were collected continuously from two or three glands separately until sweating became too slow to obtain sufficient volumes for collection. Sample volumes ranged from about $5 \mathrm{nl}$ to more than $50 \mathrm{nl}$ and were collected at 2-5 min intervals, depending on secretory rate. Usually maximal secretory rates occurred within $5 \mathrm{~min}$ of stimulation and declined spontaneously thereafter to rates of less than $1 \mathrm{nl} / \mathrm{min}$ within $45 \mathrm{~min}$. Secretory rates were determined by dividing the measured volumes of collected secretion by the period of time required for each collection.

Analysis. The content of the collected sweat samples was determined by energy dispersive $x$-ray spectometry analysis of liquid microdroplets (20). Samples were analyzed for $\mathrm{Na}, \mathrm{Mg}, \mathrm{P}, \mathrm{S}, \mathrm{Cl}$, $\mathrm{K}$ and $\mathrm{Ca}$. The analysis does not permit the detection of organic constituents or of elements with atomic weights less than Na.

Standardization. Secretory rates of individual glands vary over a wide range even among glands from the same subject. In order to compare the function of all glands, each measured secretory rate was standardized by dividing the rate of each collected sample by the maximum rate measured for that gland. The maximum rate measured for each gland was therefore always represented as $100 \%$. Curves of concentration versus rates were fitted by the method of least squares. Statistical significance was determined using Student $t$-test.

\section{RESULTS}

Rates. There was no significant difference between the average maximal secretory rates of glands from the two groups of subjects. The mean maximal rate or glands from normal individuals was $6.7 \pm 3.3 \mathrm{nl} / \mathrm{min}(n=10)$ and $7.9 \pm 7.9 \mathrm{nl} / \mathrm{min}(n=13)$ for glands from CF individuals $(P>0.35)$.

Minor components. Of the elements assayed, $\mathrm{Mg}, \mathrm{P}, \mathrm{S}$, and $\mathrm{Ca}$ were generally present at concentrations of less than $1.0 \mathrm{mM}$. Hence, these elements were neglected in the calculation of organic anion concentration, and the only major electrolytes considered were $\mathrm{Na}, \mathrm{K}$, and $\mathrm{Cl}$.

Sodium. Figure 1 shows that $\mathrm{Na}$ concentration increases as a function of sweat rate for both $\mathrm{CF}$ and control groups. The mean $\mathrm{Na}$ concentration of sweat from glands secreting at $100 \%$ observed 
maximal rate was $97 \pm 24 \mathrm{meq} /$ liter $(n=13)$ for CF glands and $44 \pm 20 \mathrm{meq} /$ liter $(n=10)$ for normal glands $(P<0.01)$. As secretory rates among CF glands fell to below 35-40\% maximal rate, $\mathrm{Na}$ concentrations were observed to fall below $60 \mathrm{meq} / \mathrm{liter}$ i.e., below the level diagnostic for cystic fibrosis clinically. At secretory rates less than $20 \%$ maximal, $\mathrm{Na}$ concentrations fell below $20 \mathrm{meq} /$ liter. The range of $\mathrm{Na}$ concentrations in sweat from single normal glands was similar to that reported for whole sweat collected from normal individuals (28). Notably, however, there is remarkedly little overlap of $\mathrm{Na}$ concentrations between the two groups when compared at similar secretory rates.

Chloride. The pattern of $\mathrm{Cl}$ concentration as a function of secretory rate largely mimics that of $\mathrm{Na}$ for both groups (Fig. 2). The average $\mathrm{Cl}$ concentration $(95 \pm 23 \mathrm{meq} / \mathrm{liter})$ at $100 \%$ maximal secretion was about the same as $\mathrm{Na}$ in fluid from CF glands. However, in sweat from normal glands, the chloride concentration (24 $\pm 12 \mathrm{meq} / \mathrm{liter})$ was about $20 \mathrm{meq} /$ liter lower than $\mathrm{Na}$ concentration. There is little overlap between $\mathrm{Cl}$ concentrations from the two groups when compared at similar secretory rates $(P$ $<0.01$ at $100 \%$ maximal rate). In normal glands, $\mathrm{Cl}$ concentrations drop to relatively low levels (less than $20 \mathrm{meq} / \mathrm{liter}$ ) at relatively high secretory rates (50\% maximal) while in $\mathrm{CF}$ glands, $\mathrm{Cl}$ concentrations were not found to fall below $20 \mathrm{meq} / \mathrm{liter}$ at even the lowest observed rates.

Potassium. The concentration of $\mathrm{K}$ in both groups is inversely related to secretory rate. At very low rates $\mathbf{K}$ may exceed $50 \mathrm{meq} /$ liter, but at higher rates the concentrations stabilize at values that are slightly higher than plasma (Fig. 3). The average concentration of $\mathrm{K}(10.8 \pm 5.8 \mathrm{meq} / \mathrm{liter})$ at $100 \%$ maximal secretory rate was significantly higher in $\mathrm{CF}$ glands than the $\mathrm{K}$ concentration $(6.3$ $\pm 1.6 \mathrm{meq} / \mathrm{liter})$ in sweat from control glands $(P<0.05)$. There was considerable overlap of $\mathrm{K}$ values at similar rates throughout the range of sweat rates (Fig. 3), but $\mathrm{K}$ concentrations were generally higher in $\mathrm{CF}$ glands than in normals.

Anion deficit. Because the sum of the $\mathrm{Na}$ and $\mathrm{K}$ concentrations

\section{SODIUM CONCENTRATION VS. RATE}

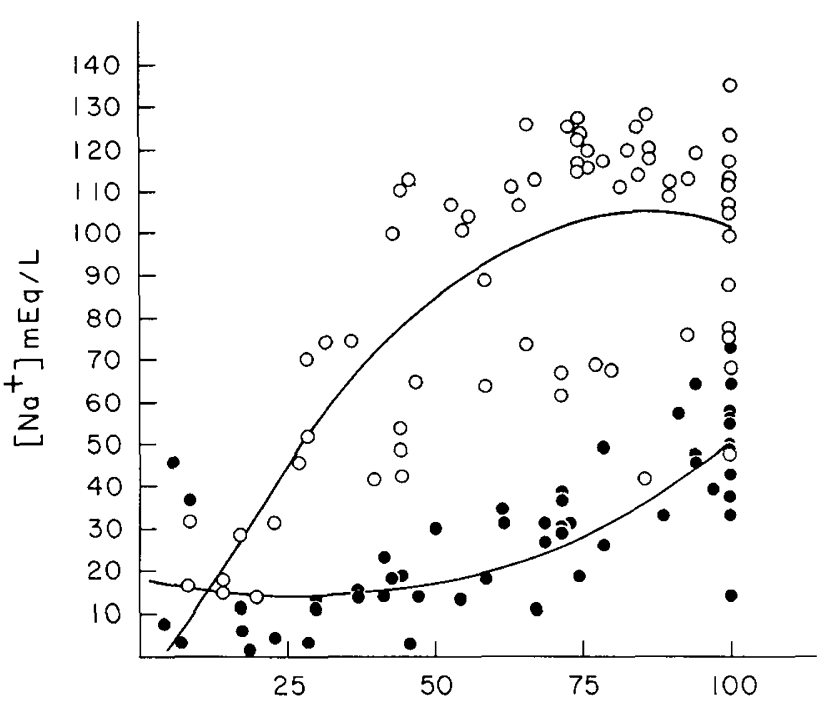

$\%$ MAX. SECRETORY RATE

Fig. 1. Sweat sodium concentration as a function of $\%$ maximal rate. The concentration of $\mathrm{Na}$ in sweat secretions from single glands is plotted as a function of the \% of maximal secretory rate observed for 11 glands from normal individuals $(\bullet)$ and 13 glands from cystic fibrosis patients (O). The consistently higher $\mathrm{Na}$ values in $\mathrm{CF}$ sweat shows that ductal reabsorption of $\mathrm{Na}$ in $\mathrm{CF}$ glands is inhibited. Note that even though $\mathrm{CF}$ sweat $\mathrm{Na}$ values reach "clinically normal levels" (below $50 \mathrm{meq} / \mathrm{liter}$ ) at low secretory rates, the $\mathrm{Na}$ in $\mathrm{CF}$ sweat is higher than normal at comparable rates. Curves were drawn by the method of least squares for the best fit of second degree polynomials.
CHLORIDE CONCENTRATION VS. RATE

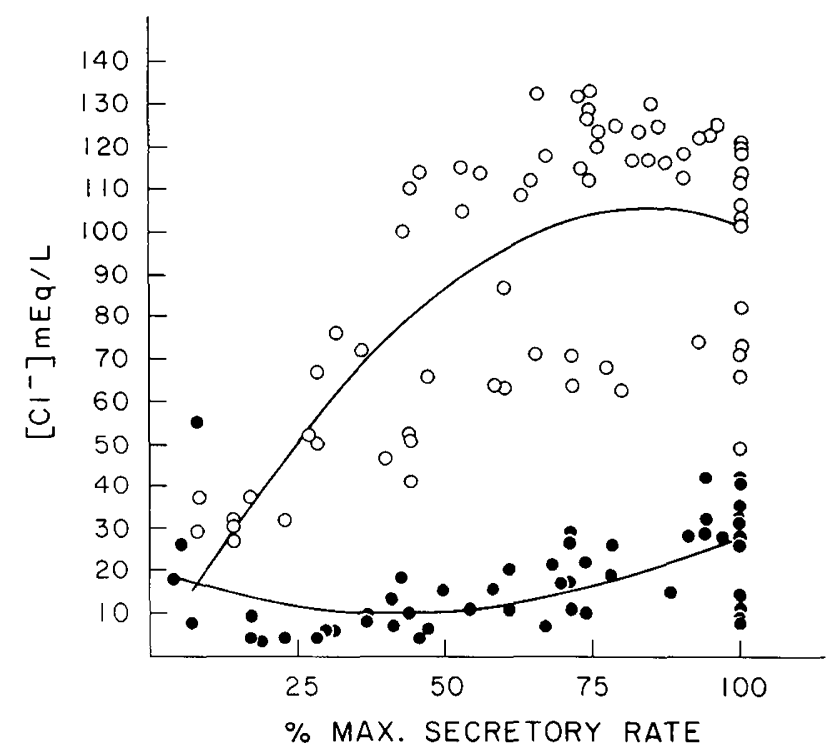

Fig. 2. Sweat chloride concentration as a function of $\%$ maximal rate. Chloride concentration values are plotted against \% maximal rate on the same samples recorded in Figure 1. Again CF values $(O)$ are well separated from normal values $(\bullet)$. Curves fitted as in Figure 1.

POTASSIUM CONCENTRATION vS. RATE

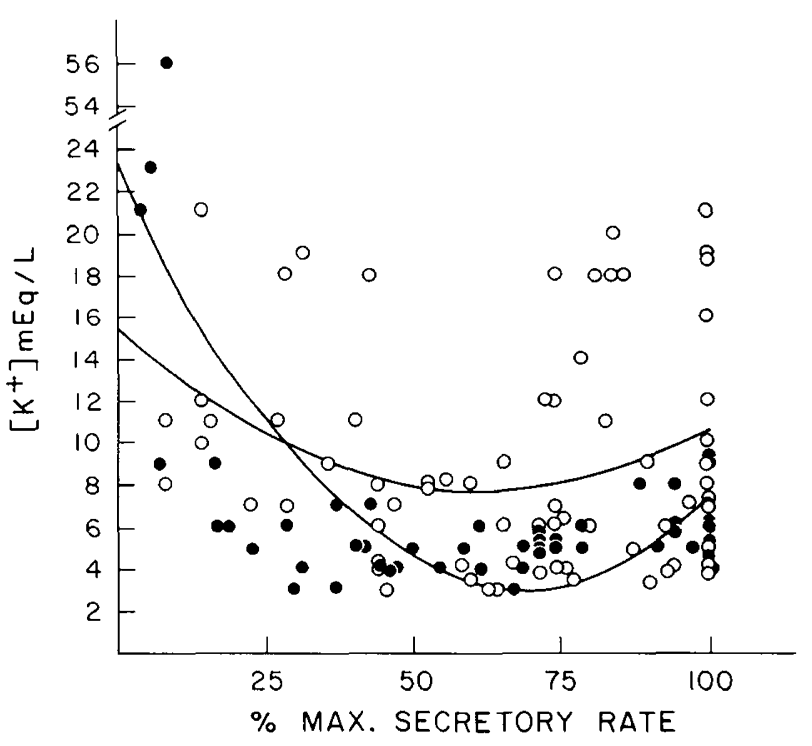

Fig. 3. Sweat potasssium concentration as a function of $\%$ maximal rate. $\mathrm{K}$ concentration values are plotted against sweat rate on the same samples recorded in Figure 1. Although $C F$ sweat $K$ values $(O)$ are generally higher than normals $(\Theta)$, there is considerable overlap of values between the two populations at all sweat rates. Curves fitted as in Figure 1.

almost always exceeds the concentration of $\mathrm{Cl}$ in sweat samples, another anion is required to satisfy electroneutrality. With the present $x$-ray analytical methodology we cannot detect $\mathrm{HCO}_{3}$ or organic components, but $\mathrm{HCO}_{3}$ and lactate are the only two anions known to be present in sweat at concentrations greater than a few mM. Lactate comprises about $0-15 \mathrm{meq} / \mathrm{liter}$ of the deficit with the remainder due to $\mathrm{HCO}_{3}(23)$. Because lactate is produced by the secretory coil, but not by the duct (24), most of the changes in the size of the anion deficit $\left(\mathrm{X}^{-}\right)$are probably due to changes in $\mathrm{HCO}_{3}$ concentration in the ducts. 
The anion deficit was calculated as $\mathrm{X}^{-}=\mathrm{Na}+\mathrm{K}-\mathrm{Cl}$. The pattern of $\mathrm{X}^{-}$excretion as reflected by this calculation is shown in Figure 4. Although there is some overlap of values at similar rates among CF and normal secretions, the anion deficit in CF sweat generally is substantially lower than that of normal sweat throughout the range of secretory rates. Furthermore, the $\mathrm{X}^{-}$concentration in normal secretions increases much more rapidly with increasing sweat rate than in $\mathrm{CF}$ secretions. At maximal rates, the mean $\mathrm{X}^{-}$ concentration was $13.2 \pm 10.5 \mathrm{meq} /$ liter in CF sections and 30.9 $\pm 10.0 \mathrm{meq} / \mathrm{liter}$ in normal gland secretions $(P<0.01)$.

\section{DISCUSSION}

Components of Reabsorption. Additional mechanisms or processes may be involved in ductal reabsorption, but our interpretation of available data suggest that electrolyte reabsorption in the eccrine sweat duct may require at least three integrated processes: (1) active $\mathrm{Na} / \mathrm{K}$ exchange at the basal membrane of ductal cells, (2) $\mathrm{Na}$ absorption and $\mathrm{H}$ secretion at the apical membrane, and (3) $\mathrm{Cl}$ reabsorption and $\mathrm{HCO}_{3}$ or organic anion $\left(\mathrm{X}^{-}\right)$secretion at the apical membrane. The present studies suggest that this latter process, $\mathrm{Cl} / \mathrm{X}^{-}$exchange, may be defective in $\mathrm{CF}$ sweat glands.

$\mathrm{Na} / \mathrm{K}$ pump. As in other ion transporting epithelia, electrolyte transport in the sweat duct is dependent upon a $\mathrm{Na} / \mathrm{K}$ exchange pump involving $\mathrm{Na} / \mathrm{K}$ ATPase in the basal membrane of the ductal cells. The pump in several other systems generally has been shown to extrude three $\mathrm{Na}$ ions in exchange for the uptake of $2 \mathrm{~K}$ ions and to be inhibited by ouabain, a specific inhibitor of $\mathrm{Na} / \mathrm{K}$ ATPase (8). This enzyme has been localized in the basal lateral membranes of isolated, perfused human sweat glands (22). Local intradermal injections of ouabain block $\mathrm{Na}$ reabsorption in vivo $(7,25)$, and in microperfused segments of sweat ducts, $\mathrm{Na}$ reabsorption is blocked when ouabain is applied to the serosal, but not luminal, side (21).

Even though profiles of $\mathrm{Na}$ versus rate (Fig. 1) showed diminished $\mathrm{Na}$ reabsorption in $\mathrm{CF}$ glands, it seems unlikely that the $\mathrm{Na} / \mathrm{K}$ pump is defective for at least three reasons: (1) in the assay of $\mathrm{Na} / \mathrm{K}$ ATPase activity, Gibbs et al. (9) found no significant difference between CF and normal sweat glands; (2) likewise, Quinton and Tormey (22) found no detectable differences in

\section{ORGANIC ANION CONCENTRATION vS. RATE}

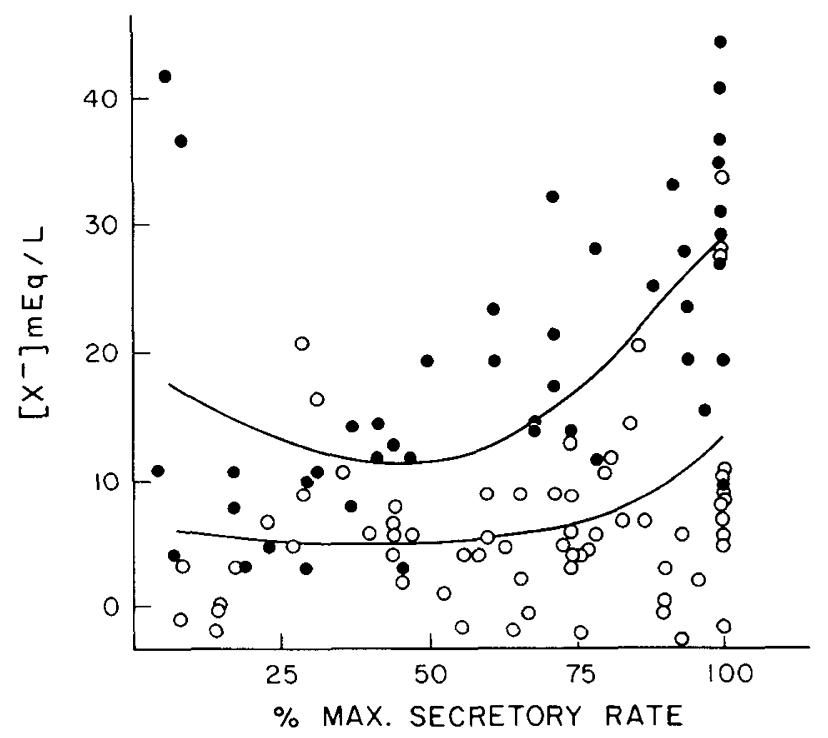

Fig. 4. Concentration of organic anions as a function of $\%$ maximal rate. The concentration of organic anions and/or $\mathrm{HCO}_{3}\left(\mathrm{X}^{-}\right)$was calculated as the difference between the sum of $\mathrm{Na}$ and $\mathrm{K}$ concentrations and the $\mathrm{Cl}$ concentrations: $\mathrm{X}^{-}=\mathrm{Na}+\mathrm{K}-\mathrm{Cl}$. In contrast to $\mathrm{Na}$ and $\mathrm{Cl}$, the concentration of this anion is generally substantially lower in $\mathrm{CF}$ sweat (O) than in normal sweat (O). Curves fitted as in Figure 1. ouabain binding patterns; and (3) if there were a defect in an ion pump as ubiquitously as $\mathrm{Na} / \mathrm{K}$ ATPase, it is very difficult to understand why only exocrine glands express transport abnormalities in the disease.

The elevated $\mathrm{K}$ concentration in $\mathrm{CF}$ sweat (Fig. 3) may, as suggested previously (28), be related to sustained high concentrations of $\mathrm{Na}$. That is, the higher $\mathrm{Na}$ loads on the distal segments of the reabsorptive duct may stimulate the $\mathrm{Na} / \mathrm{K}$ pump and thereby enhance $\mathrm{K}$ secretion in $\mathrm{CF}$ glands. At the same time, intracellular $\mathrm{K}$ may tend to equilibrate with ductal fluid resulting in high $\mathrm{K}$ in both CF and normal sweat when sweat rates are very low (Fig. 3).

$\mathrm{Na} / \mathrm{H}$ exchange. Although there is direct evidence that $\mathrm{Na}$ reabsorption across the apical membrane is coupled to $\mathrm{H}$ secretion in some systems such as the proximal tubule and intestine $(2,16$, 19), direct evidence that $\mathrm{Na}$ and $\mathrm{H}$ transport are linked in the sweat is not available. However, sweat $\mathrm{Na}$ and $\mathrm{H}$ are inversely related as a function of secretory rate. At low rates, $\mathrm{Na}$ concentration is low while $\mathrm{H}$ concentration is high, and the relative concentrations are reversed at high rates $(6,28)$. In addition, the dependence of $\mathrm{Na}$ reabsorption on $\mathrm{HCO}_{3}(23)$ suggest a possible role for $\mathrm{H}$ in $\mathrm{Na}$ transport in the duct.

The present data may also suggest a $\mathrm{Na} / \mathrm{H}$ exchange because $\mathrm{X}^{-}$increases as a function of sweat rate in normal glands and $\mathrm{X}^{-}$ remains relatively low in CF sweat (Fig. 4). Because sweat precursor fluid is isotonic with extracellular fluid $(26,27)$, the concentration of $\mathrm{HCO}_{3}$ entering the duct should be about $25 \mathrm{mM}$. The decrease in final sweat $\mathrm{X}^{-}$concentration at lower rates in normal glands must be due to either an increase in the fractional reabsorption of $\mathrm{X}^{-}$or to an increase in the fractional neutralization of $\mathrm{X}^{-}$by $\mathrm{H}$ secreted in the duct, presumably via $\mathrm{Na} / \mathrm{H}$ exchange. (30). It seems unlikely that $\mathrm{X}^{-}$is reabsorbed by the duct, because this would simply increased reabsorption of $\mathrm{X}^{-}$in $\mathrm{CF}$ glands, which are characterized by defective $\mathrm{Na}$ and $\mathrm{Cl}$ reabsorption. Therefore, we conclude that a $\mathrm{Na} / \mathrm{H}$ exchange may be a functioning part of the reabsorptive mechanism in both normal and CF sweat ducts. If the $\mathrm{Na} / \mathrm{H}$ exchange were defective in $\mathrm{CF}$, we would anticipate that less of the $\mathrm{HCO}_{3}$ entering the duct would be consumed and $\mathrm{X}^{-}$would remain equal to, or greater, than $\mathrm{X}^{-}$in normal sweat at comparable rates.

$\mathrm{Cl} / \mathrm{X}^{-}$Exchange. Recent investigations of a number of absorptive systems have implicated an anion exchange such as $\mathrm{Cl} / \mathrm{HCO}_{3}$ as being involved in $\mathrm{Cl}$ absorption. Examples of such systems include the gall bladder (13), gill (12), urinary bladder (4), colon (1), and the submaxillary main excretory duct (3). Two aspects of the present data suggest the presence of $\mathrm{Cl} / \mathrm{X}^{-}$exchange in the sweat duct.

First, in $\mathrm{CF}$ glands both $\mathrm{Cl}$ reabsorption and $\mathrm{X}^{-}$secretion appear to be inhibited. A direct explanation for simultaneous inhibition of two species transported in opposite directions is a defective exchange. A defect in a $\mathrm{Cl} / \mathrm{X}^{-}$exchange would decrease $\mathrm{Cl}$ absorption and limit the supply of luminal $\mathrm{X}^{-}$. In $\mathrm{CF}$, even partial $\mathrm{Na}$ reabsorptive would further reduce luminal $\mathrm{X}^{-}$by neutralization with $\mathrm{H}$ secreted into the duct via a $\mathrm{Na} / \mathrm{H}$ exchange (Fig. 5). The concentration of $\mathrm{X}^{-}$would rise only when the load of precursor fluid $\mathrm{X}^{-}$saturated ductal $\mathrm{H}$ secretion at high sweat rates (Fig. 4).

Second, in normal glands the concentrations of $\mathrm{Cl}$ and $\mathrm{X}^{-}$both decrease as sweat rate falls (Fig. 2 and 4). If a $\mathrm{Cl} / \mathrm{X}^{-}$exchange is a mechanism of ductal $\mathrm{Cl}$ absorption and $\mathrm{X}^{-}$secretion, lower luminal $\mathrm{Cl}$ concentrations at lower sweat rates would create less favorable transductal $\mathrm{Cl}$ gradients and reduce $\mathrm{X}^{-}$secretion. Lower ductal $\mathrm{X}^{-}$secretion would allow $\mathrm{Na} / \mathrm{H}$ exchange to consume increasing fractions of precursor fluid $\mathrm{X}^{-}$entering the duct and decrease the final sweat $\mathrm{X}^{-}$concentration at lower sweat rates as observed.

\section{SPECIAL NOTES}

First, it may be of interest clinically that CF sweat glands can, if the sweat rate is low enough, reduce $\mathrm{Na}$ concentrations to well within the range of normal values (Fig. 1). This finding clearly 

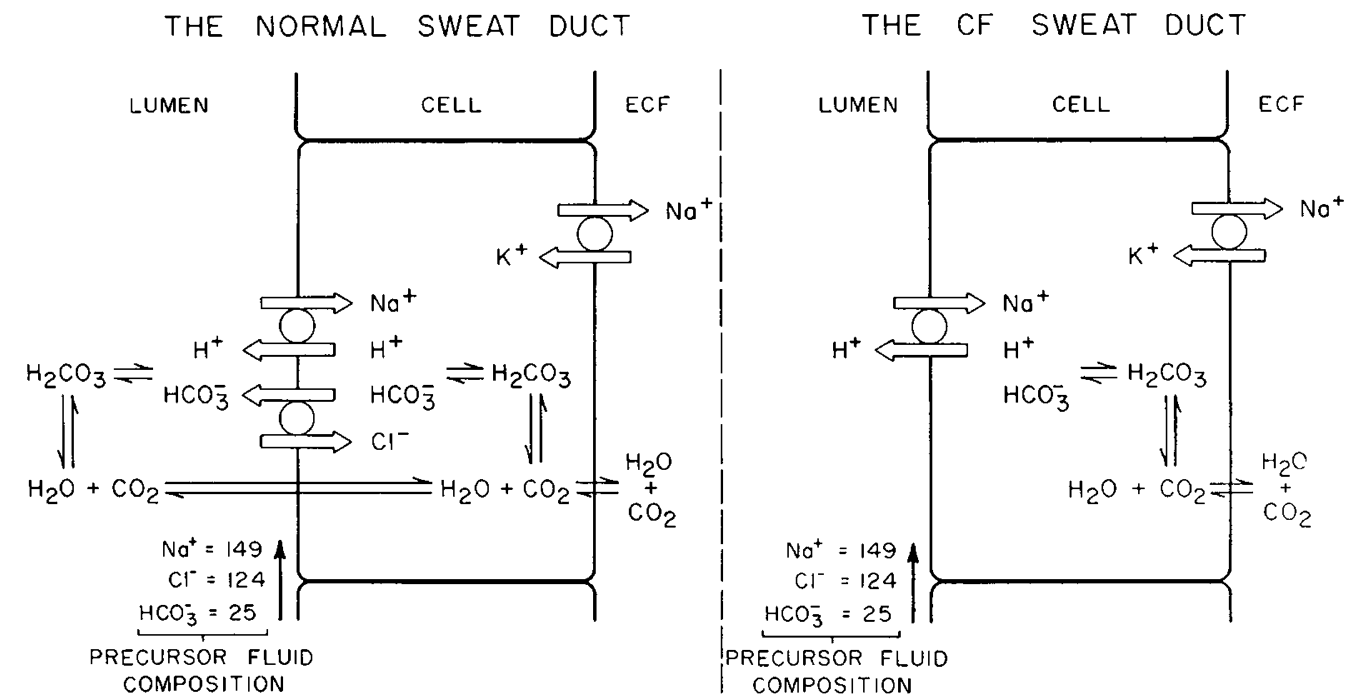

Fig. 5. Possible components of $\mathrm{NaCl}$ reabsorption in normal and cystic fibrosis sweat ducts. In both normal and $\mathrm{CF}$ ducts, it is postulated that $\mathrm{Na} /$ $\mathrm{K}$ transport at the basal membrane creates a high intracellular $\mathrm{K}$ and low intracellular $\mathrm{Na}$ concentration. Low intracellular $\mathrm{Na}$ favors the entry of $\mathrm{Na}$ from the lumen which is exchanged for $\mathrm{H}$ across the apical membrane. The secreted $\mathrm{H}$ consumes luminal $\mathrm{HCO}_{3}$ which favors additional $\mathrm{HCO}_{3}$ entry into the duct lumen. If the secretion of $\mathrm{HCO}_{3}$ is coupled to the reabsorption of $\mathrm{Cl}$, the net result is that when $\mathrm{NaCl}$ is absorbed, $\mathrm{H}_{2} \mathrm{CO}_{3}$ is formed in the lumen. The $\mathrm{H}_{2} \mathrm{CO}_{3}$ can be dissipated by conversion to $\mathrm{CO}_{2}$ and $\mathrm{H}_{2} \mathrm{O}$. In the $\mathrm{CF}$ duct, $\mathrm{Na} / \mathrm{K}$ transport and $\mathrm{Na} / \mathrm{H}$ exchange may be normal, but the $\mathrm{Cl} /$ $\mathrm{HCO}_{3}$ exchange may be defective. The defect results in the consumption of larger fractions of $\mathrm{HCO}_{3}$ in the precursor fluid consumed by secreted $\mathrm{H}$. Consequently, the anion deficit is lower and the $\mathrm{Na}$ concentration tends to approach the $\mathrm{Cl}$ concentration in $\mathrm{CF}_{\text {sweat. }} \mathrm{In}$ the model, $\mathrm{HCO}_{3}$ is used to illustrate the role of $\mathrm{X}^{-}$used in the text.

dictates that a relatively high sweat rate must be assured if false negatives are to be avoided in the use of the sweat test (10) in diagnosis. As low sweat rates we assume that other pathways may allow absorption of $\mathrm{Cl}$ and dissipation of ductal $\mathrm{H}$ so that $\mathrm{Na}$ can reach these low levels or that the anion exchange retains sufficient function to permit $\mathrm{NaCl}$ reabsorption at these low secretory loads.

Second, the present results and interpretations confirm and may explain the observation of Slegers (28) that the ratio of $\mathrm{Na}$ to $\mathrm{Cl}$ concentrations in CF sweat is always lower than the same ratio in normal sweat. The possibility that a $\mathrm{Na} / \mathrm{H}$ exchange is normal while a $\mathrm{Cl} / \mathrm{X}^{-}$exchange may be defective in $\mathrm{CF}$ ducts predicts as observed that $\mathrm{CF}$ glands should reabsorb more $\mathrm{Na}$ than $\mathrm{Cl}$. Thus, in CF glands the $\mathrm{Na} / \mathrm{Cl}$ ratio tends to be lower relative to normal glands, which reabsorbed $\mathrm{Na}$ and $\mathrm{Cl}$ almost equally.

Third, it has been known for some time that $\mathrm{HCO}_{3}$ secretion in the pancreas in $\mathrm{CF}$ individuals is severely diminished (11). If pancreatic $\mathrm{HCO}_{3}$ secretion required an anion exchange, this observation may fit well with the present suggestion of diminished $\mathrm{X}^{-}$secretion in the CF sweat gland. The proposed abnormal anion exchange may relate to an underlying genetic defect common to sweat glands, pancreas, and other exocrine glands affected in CF.

\section{OTHER FINDINGS}

Our conclusions are in conflict with those of Kaiser and Drack (15). These investigators reported that $\mathrm{HCO}_{3}$ in $\mathrm{CF}$ sweat is higher, not lower as found here, and concluded that a $\mathrm{Na} / \mathrm{H}$ exchange in CF glands is defective. Since the highest values of $\mathrm{X}^{-}$ found in any sample in the present study was slightly more than $40 \mathrm{mel} /$ liter in normal sweat, it is difficult to explain the high value of about $80 \mathrm{meq} /$ liter in CF sweat reported by these workers. The $\mathrm{HCO}_{3}$ determinations of Kaiser and Drack (15) were calculated from the Henderson-Hasselbach equations after equilibrating sweat samples with predetermined partial pressures of $\mathrm{CO}_{2}$ and measuring the equilibrium $\mathrm{pH}$. This method assumes, (1) that the $\mathrm{CO}_{2}$ of luminal fluid is in quilibrium with $\mathrm{CO}_{2}$ in the extracellular fluid, which may not be valid (29) and (2) that samples being measured are completely equilibrated at a given $\mathrm{PCO}_{2}$. If either of these conditions fails, an exponential error in calculated $\mathrm{HCO}_{3}{ }^{-}$concentration results.

\section{REFERENCES AND NOTES}

1. Argenzio, R. A. and Whipp, S. C.: Inter-relationship of sodium, chloride, bicarbonate and acetate transport by the colon of the pig. J. Physiol., 295: 365 (1979).

2. Bichara, M., Paillard, M., Leviel, F., and Gardin, J. P.: Hydrogen transport in rabbit kidney proximal tubules-Na:H exchange. Am. J. Physiol., 238: F445 (1980).

3. Bijman, J., Slegers, J. F. G., and Van Os, C. H.: Mechanism for $\mathrm{HCO}_{3}{ }^{-}$ stimulation of $\mathrm{NaCl}$ reabsorption in rabbit submaxillary main duct epithelium In Hydrogen Ion Transport in Epithelia. I. Schulz, Ed. pp 259-264 (Elsevier, North Holland Biomedical Press 1980).

4. Cohen, $\mathrm{L}: \mathrm{HCO}_{3}-\mathrm{Cl}$ exchange transport in the adaptive response to alkalosis by turtle bladder. Am. J. Physio., 239: F167 (1980).

5. Davis, P. B., Hubbard, V. S., and Di Sant'Agnese, P. A.: Low sweat electrolytes in a patient with cystic fibrosis. Am. J. Med, 69: 643 (1980).

6. Emrich, H. M. and Oelert, H.: pH-Wert und Gesamtammoniak im menschlichen SchewiB. Pflugers Archiv., 290: 311 (1966).

7. Emrich, H. M. and Ullrich, K. J.: Ausscheidung verschiedener Stoffe im SchweiB in Abhangigkeit von der SchweiBfluBrate. Pflugers Archiv., 290: 298 (1966).

8. Ernst, A. Stephen, Riddle, Clara V., and Karnaky, K. J., Jr.: Relationship between localization of $\mathrm{Na}^{+}-\mathrm{K}^{+}$-ATPase, cellular find structure, and reabsorptive and secretory electrolyte transport. Current Topics in Membranes and Transport, 13: 355 (1979).

9. Gibbs, P. H., Griffin, G., and Reimer, K.: Quantitative microdetermination of enzymes in sweat gland. Pediatr. Res., $1: 24$ (1967).

10. Gibson, L. E. and Cooke, R. E.: A test for concentration of electrolytes in sweat in cystic fibrosis of the pancreas utilizing pilocarpine iontophoresis. Pediatrics, 23: 545 (1959).

11. Hadorn, B., Johansen, P. G., and Anderson, C. M.: Pancreozymin secretin test of exocrine pancreatic function in cystic fibrosis and the significance of the result for the pathogenesis of the disease. Can. Med. Assoc. J., 98: 377 (1968).

12. Haswell, M. S., Randall, D. J., and Perry, S. F.: Fish gill carbonic anhydrase: acid-base regulation or salt transport? Am. J. Physiol., 238: R240 (1980).

13. Heintze, K., Petersen, K. U., Olles, P., Saverymuttu, S. H., and Wood, J. R. Effects of bicarbonate on fluid and electrolyte transport by the guinea pig gallbladder: a bicarbonate-chloride exchange. J. Membrane Biol., 45: (1979).

14. Kaiser, D.: Excretion of protons, bicarbonate, and cations by the single sweat gland of patients with cystic fibrosis. In: Fundamental Problems of Cystic Fibrosis and Related Diseases, Eds. J. A. Mangos and R. C. Talamo. p 247256 (Symposia Specialists, New York. 1973).

15. Kaiser, D. and Drack, E.: Diminished excretion of bicarbonate from the single sweat gland of patients with cystic fibrosis of the pancreas. Europ. J. Clin. Invest., 4: 261 (1974).

16. Kinsella, J. L. and Aronson, P. S.: Properties of the $\mathrm{Na}-\mathrm{H}$ exchanger in renal microvillus membrane vesicles. Am. J. Physiol., 7(6): F461 (1980).

17. Mangos, J. A.: Microperfusion study of the sweat gland abnormality in cystic fibrosis. Texas Rep. Biol. Med., 31: 652 (1973).

18. Mandel, I. D., Kutscher, A., Denning, C. R., Thompson, R. H., Jr., and Zegarelli, E. V.: Salivary studies in cystic fibrosis. Amer. J. Dis. Child., 113: 431 (1967). 
19. Murer, H., Hopfer, V., and Kinne, R.: sodium/proton antiport in brush-border membrane vesicles isolated from rat small intestine and kidney. Biochem. J., 154: 597 (1976).

20. Quinton, P. M.: Techniques for microdrop analysis of fluids (sweat, saliva, urine) with an energy-dispersive $x$-ray spectrometer on a scanning electron microscope. Am. J. Physiol., 234(3): F255 (1978).

21. Quinton, P. M.: Effects of some transport inhibitors on secretion and reabsorption in intact and perfused single human sweat glands. Pflugers Archiv., In Press (1981).

22. Quinton, P. M. and Tormey, J. McD.: Localization of Na/K-ATPase sites in the secretory and reabsorptive epithelia of perfused eccrine sweat glands: a question to the role of the enzyme in secretion. J. Membrane Biol., 29: 383 (1976).

23. Sato, K.: The physiology, pharmacology, and biochemistry of the eccrine sweat gland. Rev. Physiol. Biochem. Pharmacol., 79: 51 (1977).

24. Sato, K. and Dobson, R. L.: Glucose metabolism of the isolated eccrine sweat gland. II. The relation between glucose metabolism and sodium transport. J. Clin. Invest., 52: 2166 (1973).

25. Sato, K., Dobson, R. L., and Mali, J. W. H.: Enzymatic basis for the active transport of sodium in the eccrine sweat gland. Localization and characterization of Na-K ATPase. J. Invest. Derm., 57: (1970).

26. Schulz, I. J.: Micropuncture studies of the sweat formation in cystic fibrosis patients. J. Clinical Invest., 48: 1470 (1969).

27. Schwartz, I. L. and Thaysen, J. H.: Excretion of $\mathrm{Na}$ and $\mathrm{K}$ in human sweat. $J$. Clinical Invest., 34: 114 (1955).

28. Slegers, J. F. G.: Patho-physiological studies of the sweat gland. Pflugers Archiv., 290: 231 (1966).
29. Sohtell, $\mathrm{M}: \mathrm{PCO}_{2}$ of the proximal tubule fluid and the efferent blood in the rat kidney. Acta Physiol. Scand., 105: 137 (1979).

30. Alternatively, we might imagine that for some reason $\mathrm{CF}$ glands elaborate a $\mathrm{HCO}_{3}$ depleted precursor fluid. But this possibility seems unlikely because (l) at very high sweat rates $\mathrm{X}^{-}$in $\mathrm{CF}$ sweat approaches normal concentrations (Fig. 4) and (2) maximal secretory rates are approximately the same for CF and normal glands; if the $\mathrm{CF}$ secretory coil secreted fluid deficient in $\mathrm{HCO}_{3}$ we might expect the CF sweat rate to be lower than normal.

$A$ reduced $\mathrm{X}^{-}$might also be observed if $\mathrm{CF}$ sweat contains a relatively higher concentration of a cation such as $\mathrm{NH}_{4}$, which is also "invisible" by $\mathrm{x}$-ray analysis as applied here. However, a decrease in $\mathrm{X}^{-}$as a function of increased $\mathrm{NH}_{4}$, for example, would also support a defective $\mathrm{Cl} / \mathrm{X}^{-}$exchange. In the presence of such a defect, luminal $\mathrm{H}$ should rise, thereby favoring ionic tapping of a diffusible uncharged species $\left(\mathrm{NH}_{3}\right)$ as an impermeable ion $\left(\mathrm{NH}_{4}\right)$ in the duct lumen. The significance of this possibility requires further investigation.

31. Requests for reprints should be addressed to: Dr. Paul M. Quinton, Division of Biomedical Sciences, University of California, Riverside, Riverside CA 92521.

32. The technical assistance of Miss Ellen Atkinson is deeply appreciated. This work was made possible by grants from the Getty Oil Company, the Gillette Company, and the National Institute of Health (USPHS \#ROI AM 20356 and KO4 AM 00324).

33. We deeply appreciate the assistance of Dr. Alan Osher and the UCLA Cystic Fibrosis Center in securing cystic fibrosis patients.

34. Received for publication August 27, 1981.

35. Accepted for publication December 4, 1981. 